\section{THE LEGAL SERVICES ACT: A LAW SOCIETY PERSPECTIVE}

On October 30, 2007 the Legal Services Act finally received Royal Assent, marking the final stage of a long and detailed process of regulatory reform.

The Law Society has always supported the main principles of the proposed reforms, based substantially on the proposals in the 2004 Clementi Report. Even so, we have had a number of major concerns on specific issues, and have worked with both Government and Opposition parties to improve the Bill, both during pre-legislative scrutiny and in the final Bill's passage through Parliament. We have also engaged in consistent dialogue with the profession and other major stakeholders throughout the process of development. Amidst all the detailed scrutiny and debate, however, certain issues have remained firm priorities.

First, we have always sought to ensure that the Legal Services Board should be clearly independent, both from the professions and from Government.

The initial proposition in the Bill that the Secretary of State for Justice should appoint the Chair of the Board could potentially be viewed as a threat to the Board's independence. During the passage of the Bill, however, some important concessions were achieved on this point. Ministerial responsibility under the Act will rest with the Lord Chancellor (who has a statutory duty to uphold the rule of law), and who will have a duty to consult the Lord Chief Justice fully on appointments to the Board. More generally, the Act now includes a requirement to maintain the independence of the profession as part of the regulatory objectives.

As part of the general principle of strengthening professional independence, and in line with the Clementi Report's recommendations, all approved regulators of legal services will be required to separate their representative and regulatory roles. The Law Society has already taken pre-emptive steps to achieve this. Regulatory functions, while still funded through the Law Society, are now carried out by the Solicitors Regulation Authority (SRA), while the Law Society will continue to focus on representing the interests of solicitors, developing international initiatives, and influencing law and procedure. The Bar Council has taken similar steps in anticipation of the new framework.

As a prospective approved regulator, the Law Society has focused consistently on the need for the Bill make it clear that lead responsibility for regulating the professions rests with the approved regulators, and that the Board should seek to resolve matters informally before exercising its powers. Finally, and perhaps most importantly, the Board should not intervene in the decision of an approved regulator, except where its actions were plainly unreasonable. The Law Society is satisfied that the final form of the Act properly secures the independence of the profession from Government.

\section{Articles}

Trends in the South African Constitutional Court's jurisprudence on property protection and regulation

The private company in Spanish law

Institute News

\section{Articles (cont'd)}

Reference and meaning: the ambiguity of definite descriptions in wills

Judicial activism and overreach in India

The Law Society also welcomes the potential for alternative business structures (ABS) to develop once the Act is in force. Again, however, we had some important concerns in this area. We generally felt that the Bill dealt effectively with the potential risks posed by external investment, combining best practice from the FSA regime for regulated investors with statutory safeguards specific to legal services, and giving robust protection to the professional ethical obligations at stake. We were also reassured to know that the law firms concerned will be regulated in the same way as other law firms, and by the same regulators, so that the same public and consumer protections will be in place.

Our principal remaining concern in relation to $\mathrm{ABS}$ therefore was that the Bill did not give adequate weight to the need to ensure access to justice in the face of a potentially more commercialised market. We wanted it to be clear that the new regime would not simply enable new providers to cherry-pick the most profitable services, while adversely affecting more vulnerable clients or limiting access in particular areas. We are therefore pleased to see that the final Bill included a statutory duty on ABS regulators to ensure that appropriate consideration was given to access when granting licences to new ABS firms.

The Law Society also supports the establishment of the Office for Legal Complaints to handle complaints about solicitors' firms and other legal practices, particularly since it has now been made clear that the OLC will not be able to penalise respondents in cases where they are not at fault. The OLC will have no involvement in disciplinary matters, however, which will remain the responsibility of individual approved regulators.

We have achieved virtually all of our objectives during the Bill's passage through Parliament, and we believe that the new Act provides a sound basis for regulation of legal services in future. We will continue to work to ensure that the profession is able to be actively involved in the implementation of the new framework, and that both solicitors and their clients can benefit fully from the changes.

Government Relations Directorate, Law Society 